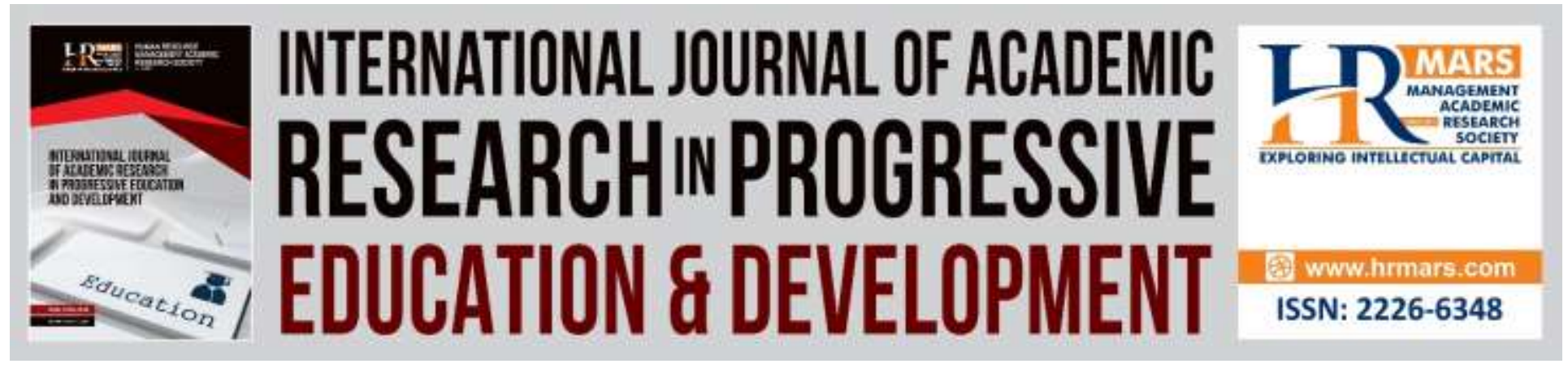

\title{
Use of Delphi Fuzzy Technique in Selection of Key Components of Self-Defense Training for Preschool Child Sex Education
}

\author{
Zarina Eshak, Azizah Zain, Norsyimar Akmar Hashim
}

To Link this Article: http://dx.doi.org/10.6007/IJARPED/v9-i2/7292

DOI:10.6007/IJARPED/v9-i2/7292

Received: 25 March 2020, Revised: 26 April 2020, Accepted: 19 May 2020

Published Online: 17 June 2020

In-Text Citation: (Eshak et al., 2020)

To Cite this Article: Eshak, Z., Zain, A., \& Hashim, N. A. (2020). Use of Delphi Fuzzy Technique in Selection of Key Components of Self-Defense Training for Preschool Child Sex Education. International Journal of Academic Research in Progressive Education and Development, 9(2), 179-191.

Copyright: (C) 2020 The Author(s)

Published by Human Resource Management Academic Research Society (www.hrmars.com)

This article is published under the Creative Commons Attribution (CC BY 4.0) license. Anyone may reproduce, distribute, translate and create derivative works of this article (for both commercial and non-commercial purposes), subject to full attribution to the original publication and authors. The full terms of this license may be seen at: $\underline{\text { http://creativecommons.org/licences/by/4.0/legalcode }}$

Vol. 9(2) 2020, Pg. 179 - 191

http://hrmars.com/index.php/pages/detail/IJARPED

JOURNAL HOMEPAGE

Full Terms \& Conditions of access and use can be found at http://hrmars.com/index.php/pages/detail/publication-ethics 


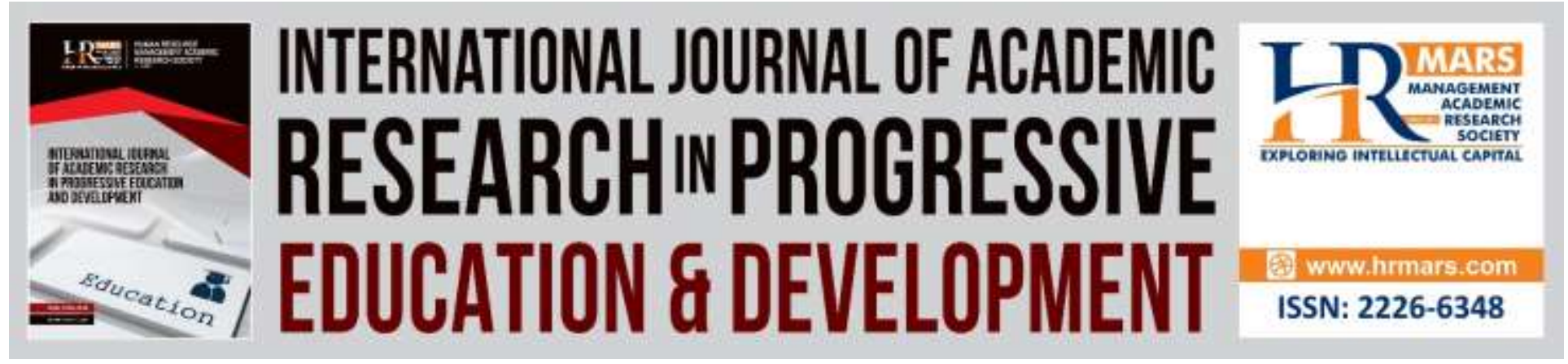

\title{
Use of Delphi Fuzzy Technique in Selection of Key Components of Self-Defense Training for Preschool Child Sex Education
}

\author{
Zarina Eshak, Azizah Zain, Norsyimar Akmar Hashim \\ National Children's Development Research Center (NCDRC), Sultan Idris Education University
}

\begin{abstract}
This article discusses the use of Fuzzy Delphi in defining key components in Self-Defense Training for preschool children. Because the scale of key components has been chosen to provide martial arts training to preschool children, the selection of these components can be seen as a process of decision making by several experts in the fields of early childhood education, martial arts, medicine-pediatrics, and counseling. This study aims to provide a systematic approach to component selection and key component sequencing, in which there are two phases of the procedure. The first stage uses the Delphi Fuzzy Method to obtain expert consensus on the components of martial arts training. In the second stage, the process is used to determine the importance of each of these criteria as a key title that can be measured from the positioning of the component. The results show that all the elements (items) for the main components of SelfDefense Training meet the threshold value (less than 0.2), and the approval rate of expert groups is over $75 \%$. The main components of Self-Defense Training include family relationship activities, relationships with outsiders, emotional and social health management activities, physical \& reproductive health, and safety activities. These findings indicate that all of the key components are necessary to establish a martial arts education based on Self-Defense for preschoolers based on expert consensus.
\end{abstract}

Keywords: Sexuality Education, A Key Component of Self-Defense Training, Fuzzy Delphi, Research Expert.

\section{Introduction}

Some of the problems during preschool child sexual education are closely linked to the problem of increasing sexual crime. It is evident from the report that the number of cases related to pedophilia crime in Malaysia has also increased by 38 percent, compared to previous years (ONLINE Berita Harian, 2019). The increase, in this case, indicates an increase in problems with the sexual education channel at home and school. Among the issues are the failure of sexual education and some of the constraints that come with it from home. Sadly, most children are 
sexually abused as a result of those who have a close relationship with the child themselves. This statement is in line with a study by (Ryan, 2015) and a report from the Ministry of Social and Family Development (MSF) (The Streets Times Singapore, 2017) showing that children are at higher risk of being sexually abused by someone they know in the neighborhood or own family members than strangers. Children need to be protected from parents and even need to know how to keep themselves safe. The way they are protected is by looking at the situation or situation of the children at home. Whether they are given basic knowledge of children's sexual education at home or not (Reynolds, 2014), provide basic understanding of lesbian, gay, bisexual \& transsexual (LGBT) lifestyles (Gowen \& Winges-Yanez, 2014) or not, do parents isolate children's bedding of different genders (Karimuddin et al., 2017), whether parents explain the limitations of socializing with family members, caregivers, relatives and whether there is any control over television viewing involving 18 SX children at home (Allotey et al., 2011). As such, five key components have been identified and will be used as the primary learning for child protection training, which are the components of family relationships, emotional \& social health, physical \& reproductive health, relationships with outsiders, and personal safety. These five components include ways and means of defending yourself in terms of relationships with family members, peers, caregivers, and neighbours. In addition, emotional and social, physical, and reproductive health and personal safety are emphasized in learning to defend this way.

The Delphi method is a widely used and widely accepted approach in collecting data for a study based on the consensus of a group of experts on a given issue (Ahmad et al., 2014). The strength of this method has also resulted in various techniques for obtaining empirical data, such as the Fuzzy Delphi (FDM) method. Speaking of the Fuzzy Delphi (FDM) method, it is a method of measurement that is modified based on the Delphi method. This method was introduced by Kaufman and Gupta in 1988. This Fuzzy Delphi (FDM) method is a combination of the fuzzy numbering set and the Delphi method itself (Yusop, 2013). This implies that this is not a new approach as it is also based on the classic Delphi method whereby the respondents involved must be among the experts who are well-versed in the field of study. These improvements have indirectly enabled the Fuzzy Delphi (FDM) method to be a more useful measurement approach whereby it has been able to solve problems of uncertainty and uncertainty for a given issue. Previous literature shows that the Fuzzy Delphi method (FDM) is a combination of the traditional (classical) Delphi method and the fuzzy set theory (fuzzy). This theory of fuzzy sets was introduced by a mathematician in 1965 called Lotfi Zadeh, and it works as an extension of classical set theory where each element in a set is evaluated based on a binary set (Yes or No). The fuzzy set theory also allows for a continuous assessment of each element studied. Values for fuzzy numbering is range from 0 to 1 or in units of intervals $(0,1)$ (Asra et al., 2014).

The study consists of two stages: the first stage is to establish the key factors for the evaluation of the key components and to use Fuzzy Delphi to reach a consensus from three categories of specialists - early childhood education, martial arts, and pediatric medicine. The selection of these three expert categories is to select the best criteria from the component selection standpoint and to identify the essential factors to consider when selecting components. The second phase is also based on Fuzzy Delphi, a process of consulting with experts from various 
Vol. 9, No. 2, 2020, E-ISSN: $2226-6348$ @ 2020 HRMARS

fields to learn its importance from a variety of criteria, to obtain a measurement index to select key components as the main topic of Self-Defense Training for Preschool Children.

\section{Objective}

The following research questions have been proposed as the basis for this study :

1. Identify key components that should be included in developing Self-Defense Training for preschoolers based on expert opinion.

2. Identify the sequences (priorities) of each of the key components of Self-Defense Training for preschoolers based on expert opinion.

\section{Theory}

The framework of this research theory is based on a literature review on sexuality education, sexuality education models, teaching and learning theories, and pedagogical models used in the study. The theoretical framework for this study is a combination of theories and models; Theories underlying Sigmund Freud's Psychosocial Theory (the concept of personality structure) and Maslow's Theory of Needs (1943) (Schmidt et al., 2015); Curriculum Model (Tyler, 1949); Fitts and Posner Model 1972 (Bugdadi et al., 2018); Sex Cycle Models (Dalley, 2012); and SIM Training Models (Milano \& Ullius, 1998).

An important concept in Freud's psychoanalytic theory is the concept of personality structure divided into the id, ego, and superego. Social connections are also expanding. Social communication was originally only around family members, then evolved to communicate with caregivers, neighbors, peers, and teachers at the school. This part develops gradually as children develop moral values. By controlling Id's desire, sexuality education can be adapted to children's learning. Collaboration between parents and teachers is essential to ensure that teaching sex education is not only theoretically practical but also practical. According to Maslow's Theory of Needs, student needs include basic needs of safety, love, self-esteem, and self-sufficiency. The needs and needs of students need to be met to ensure a positive self-concept in line with the content of a curriculum that they want to design. According to Ozguner \& Ozguner (2014), Maslow's level of motivation needs to be met through three types of rewards; first, the highest level of achievement is fully achieved through intrinsic rewards such as social honors, awards, prestigious awards, social accolades, and reputations; secondly, in terms of meeting the needs of self-respect, it is derived from intrinsic and extrinsic rewards; Third, at the level of social needs as well as physiological needs, it is obtained through extrinsic rewards in nature.

The next curriculum model to be used in this study is Tyler's Curriculum Model (1949), which is considered to be the most dominant and validated curriculum development model (Asra et al., 2014). In this model, the main question is the effort towards formulating the curriculum objectives, whereas the second question refers to the choice of content or student learning experience. The third question then led to efforts to organize the learning experience and the latter to the question of the effectiveness of the curriculum evaluation (Ahmad, 2017). Gansen recommends that partnerships between professionals working in the field of sex should be 
explored to develop a sexuality education curriculum for preschool children (Gansen, 2017). This will act to support martial arts training to address current issues in sexual crime and, at the same time, clarify the appropriate content for martial arts training for preschool children. The next model to be used in the study of the development and collection of information in Martial Arts is Fitts and Posner's (1972) Model. This study uses the Fitts and Posner Models as a framework to reflect current progress in motor learning. Fitts and Posner's motor learning model proves that if a person is trained with intentional training, then they will progress through the phase of autonomous motor ability. This view is supported by (Bugdadi, 2018) who says in his study that Fitts and Posner's motor model is in line with the concept of automatic learning or accidental learning that improves upon completing residency training. SIM Training Models are also used in the development of PEKASA Fitness Modules based on Self-Defense Training. The SIM model stands for Sequential Interactive Model, which is a model used as the basis for shaping a training that is intended to be implemented. It focuses on five key components of training that are goals and objectives, keywords that include content to be trained, the flow of training, training aids, and assessment of training (Robinson, 2017). The selection of SIM models in this study is in line with the characteristics of the training formations that are intended to be developed that are martial arts training.

\section{Theoretical Framework}

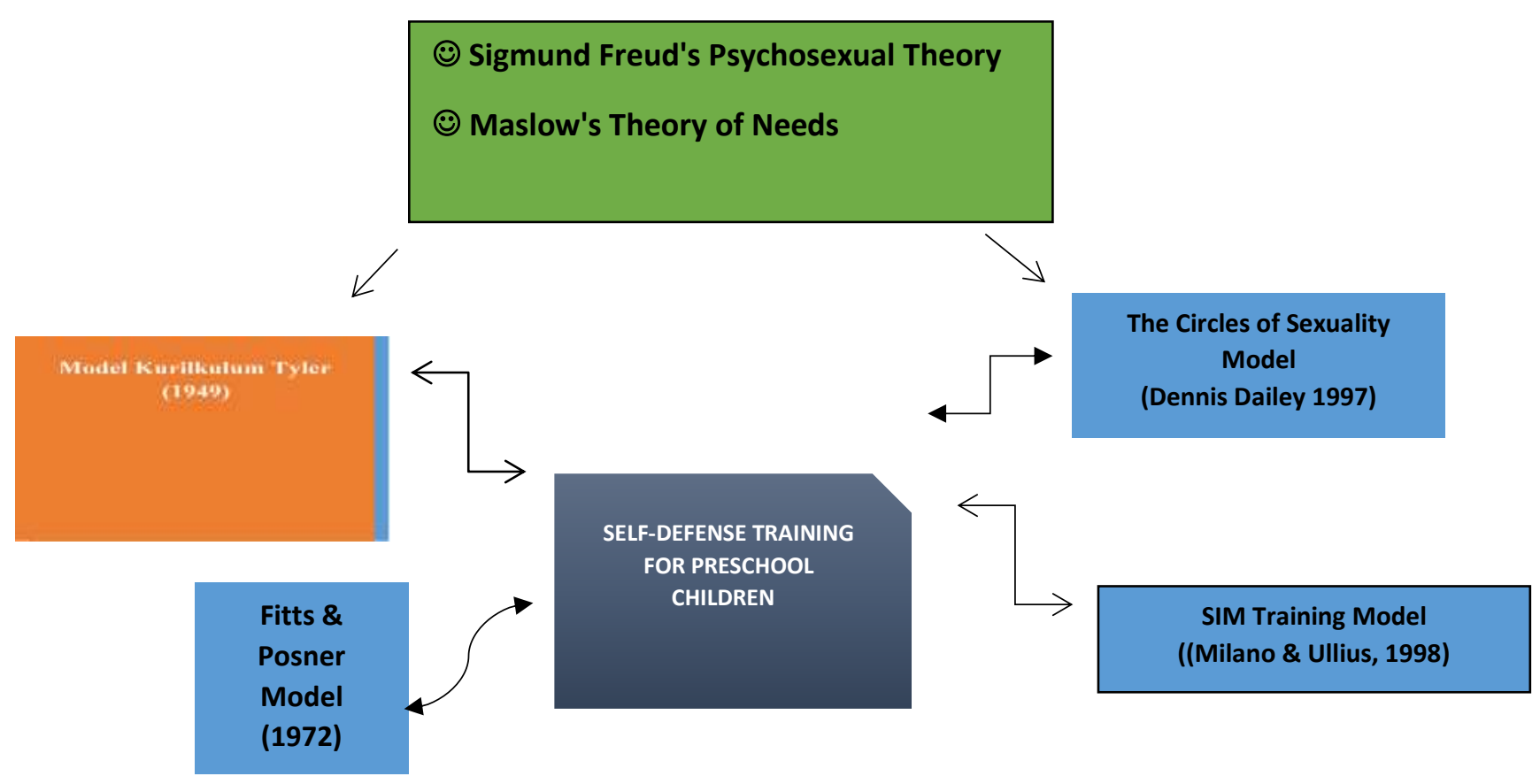




\section{Research Methodology}

There are two main things in the Fuzzy Delphi (FDM) method, namely the Triangular Fuzzy Number and Defuzzification Process. The Triangular Fuzzy Number is composed of the values $\mathrm{m} 1$, $\mathrm{m} 2$, and $\mathrm{m} 3$, where $\mathrm{m} 1$ represents the smallest value, $\mathrm{m} 2$ represents the most plausible value, and $\mathrm{m} 3$ refers to the maximum value. The three values in this Triangular Fuzzy Number can be seen in Figure 3.3, which shows a triangular graph against triangular values.

Based on the diagram below, it shows that these three values are also in the range 0 to 1 , and it corresponds to a fuzzy number (Ragin, 2007).

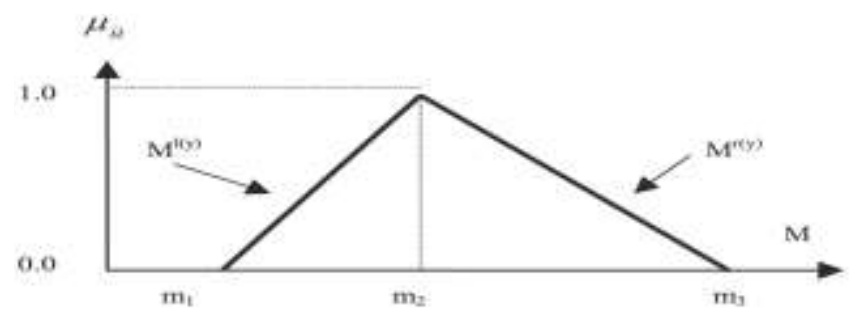

In the Triangular Fuzzy Number stage, there are two conditions that must be met to determine the acceptability of a component studied by the expert consensus; Determination of this threshold value (d) is based on a predefined formula. Both of these conditions will be explained in the section on conducting the study using the Fuzzy Delphi (FDM) method in the following subtopics.

In general, the defuzzification process refers to a process of determining the ranking of each construct, component, element, issue, variable, and sub-variable in the study. The purpose of this process is to help the researcher see the level of needs of the variables and sub-variables needed. It can also be used to determine the rankings and priorities of each element studied. This ranking process will help generate the data according to the consensus of experts who act as the respondents of the study. There are three formulas that can be used in the defuzzification process. Researchers can choose any of these three formulas to determine the ranking in their study. The three formulas in this process are as follows:
i. $A_{\max }=1 / 3 *(a 1+a m+a 2)$
ii. $A_{\max }=1 / 4 *(a 1+2 a m+a 2)$
iii. $A_{\max }=1 / 6 *(a 1+4 a m+a 2)$

In the defuzzification process, there is also a condition that must be met to indicate the acceptance of a specialist group for a component studied in which the expected use of the median value known as the alpha-cut ( $\alpha$-cut) value is used.

\section{Research Design}

This study is a quantitative study that applied the Fuzzy Delphi Technique to obtain expert consensus on the main components of martial arts training and to identify the position of each 
component of martial arts training based on expert consensus. This method involves the use of fuzzy set theory, which has been incorporated into the classical Delphi method, where the Likert scale chosen by the expert will be converted to a fuzzy scale using fuzzy numbering consisting of binary terms $(0,1)$. This fuzzy numbering integration will produce three values, namely the minimum value, the most reasonable value, and the maximum value to be chosen by the expert.

\section{Instruments Study}

This study used questionnaires as instruments for obtaining quantitative data on the components of Self-Defense Training for children. This questionnaire is through expert opinion and refinement and has gained language validity and content validation from field experts and curriculum specialists. The use of the questionnaire is to meet the criteria and conditions of use of the Delphi fuzzy technique, which involves the use of mathematical formulas to obtain expert consensus. The instrument used by the researcher is based on the research needs of the researcher.

\section{Results and Discussion}

\section{Part I - Expert Demographic Insights}

The analysis in the demographic section of the expert involved five items on gender, education level, experience, position, and area of expertise. This study involved 17 experts. Most experts have 5-26 years of experience and are directly involved in sexuality education, pediatric medicine, counseling, and martial arts. Based on the argument presented by Creswell \& Creswell (2017), he explicitly concludes that experts who have served between five and ten years can be categorized as experts. A total of 17 specialists, including preschool teachers, counselors, pediatric physicians, and martial arts experts from various fields of expertise. These experts are also selected on a voluntary basis. The number of experts in this application of Delphi's Fuzzy Technique is in agreement with Jones and Twiss (1978), who stated that the number of experts in Delphi studies is 10 to 50 experts. It has also been asserted by Adler and Ziglo (1996) that the number of experts is 10 to 15 experts in the event of a high level of expert agreement and uniformity. 
INTERNATIONAL JOURNAL OF ACADEMIC RESEARCH IN PROGRESSIVE EDUCATION AND

DEVELOPMENT

Vol. 9, No. 2, 2020, E-ISSN: 2226-6348 @ 2020 HRMARS

Table 1 shows demographic information and the number of experts involved in this study.

Table 1 : Respondent Information

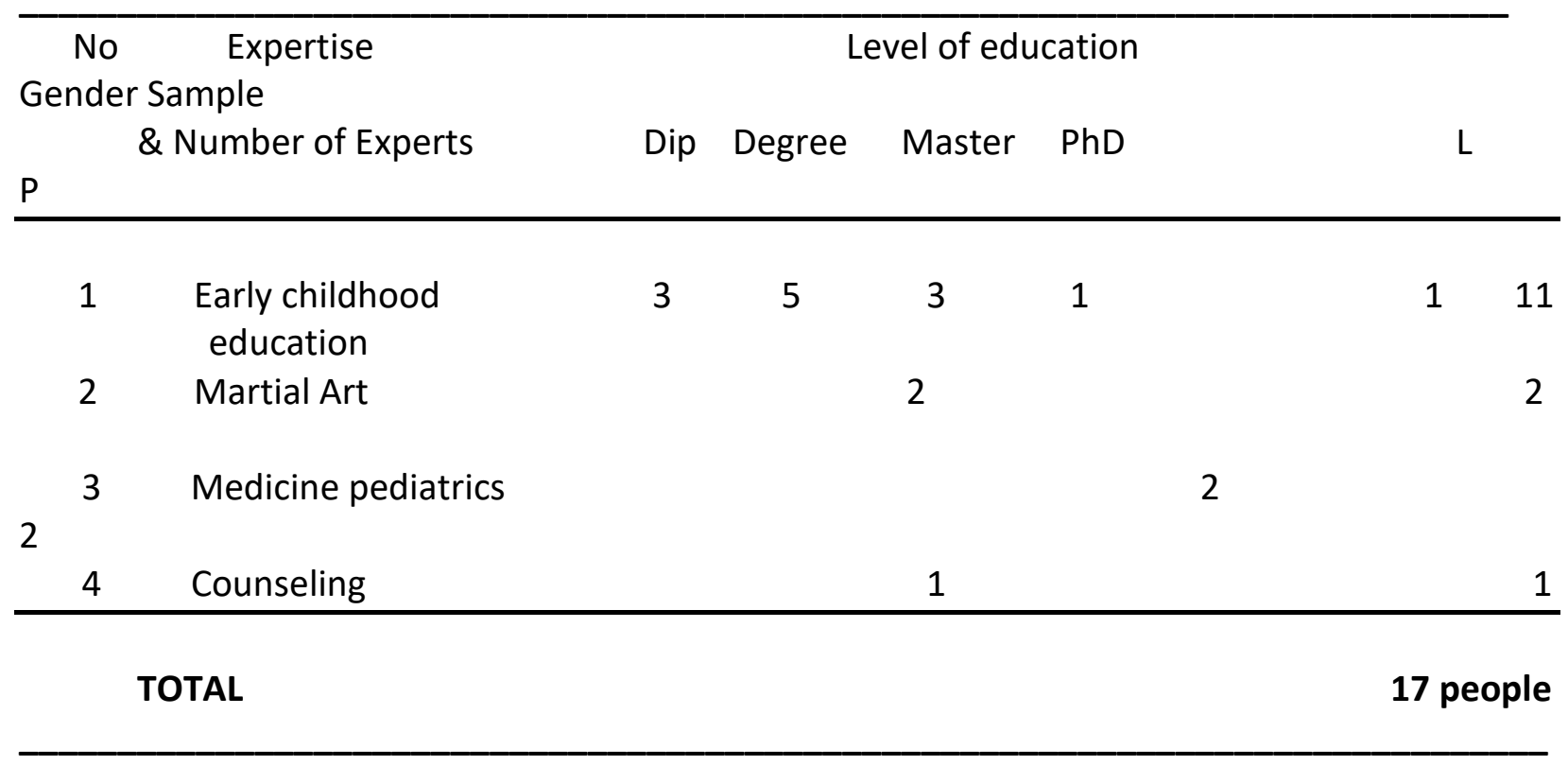

\section{Part II - Findings the Key Components of Martial Training}

Table 2 shows the findings of the main components of Martial Exercise. This data consists of the threshold value of each item ( $d$ item), the threshold value of the constructor ( $d$ constructor), and the item's position based on expert agreement. 
INTERNATIONAL JOURNAL OF ACADEMIC RESEARCH IN PROGRESSIVE EDUCATION AND DEVELOPMENT

Vol. 9, No. 2, 2020, E-ISSN: 2226-6348 @ 2020 HRMARS

Table 2: Five Key Components of Self-Defense Training based on Fuzzy Delphi Analysis (FDM) and expert panel recommendations.

Specialists

Key Components

$12 \quad 3 \quad 4 \quad 5$

1

2

0.0

0.1

0.0

0.1

0.0

0.0

0.1

0.0

0.1

0.0

3

0.0

0.1

0.0

0.1

0.0

4

0.0

0.1

0.0

0.1

0.0

5

0.0

0.1

0.0

0.1

0.0

6

0.0

0.1

0.0

0.1

0.0

7

0.0

0.1

0.0

0.1

0.0

8

9

10

0.0

0.1

0.0

0.1

0.0

0.0

0.1

0.0

0.1

0.0

11

0.0

0.1

0.0

0.1

0.0

12

0.0

0.1

0.0

0.1

0.0

13

0.0

0.1

0.0

0.1

0.0

14

0.0

0.1

0.0

0.1

0.0

15

0.0

0.1

0.0

0.1

0.0

16

0.0

0.1

0.0

0.1

0.0

17

0.0

0.1

0.0

0.1

0.0

0.0

0.1

0.0

0.1

0.0

\begin{tabular}{lccccc}
\hline $\begin{array}{l}\text { Threshold }(\mathrm{d}) \text { value } \\
\text { Each Component } \\
\text { Key }\end{array}$ & 0.000 & 0.032 & 0.017 & 0.044 & 0.00 \\
\hline $\begin{array}{l}\text { Percentage Deal } \\
\text { Expert (\%) }\end{array}$ & $100 \%$ & $100 \%$ & $100 \%$ & $100 \%$ & $100 \%$ \\
\hline & & & & & \\
\hline
\end{tabular}

Table 2 also shows that the main components of the Martial Arts Exercise are agreed upon by a group of experts based on the criteria set forth in the analysis of the Fuzzy Delphi Technique, which is a threshold value of construct (d) and $\geq 75 \%$. 
Vol. 9, No. 2, 2020, E-ISSN: 2226-6348@ 2020 HRMARS

\section{Part III - Findings of the Key Components of Self-Defense Training}

Table 3 shows the fuzzy score values that have been ranked (Ranking) based on expert consensus. Table 3: Ranking of each item in the Main Components of Self-Defense Training for Preschool Children.

No Item Main Components of Self-Defense Training Fuzzy Delphi Ranking

\begin{tabular}{llll}
\hline 3 & Family Relationship Activities & 0.961 & 1 \\
4 & Relationships with outsiders & 0.949 & 2 \\
2 & Emotional and Social Health Management Activities & 0.955 & 3 \\
1 & Physical \& Reproductive Health Activities & & 0.967 \\
4 & & 0.967 & 5 \\
5 & Safety Activities. & & \\
\hline
\end{tabular}

The main purpose of this study was to determine the expert's agreement on the main components of Self-Defense Training. This component was selected based on the recommendation of experts that all five of these components are very important to be practiced by preschool teachers. The findings show that all the items in this component are expertly agreed upon and that these items are needed by teachers in the process of teaching sex education to children based on Self-Defense Training. Family relationship activity items have the highest rank and priority, indicating that children's relationships with family members should be given priority as this is the first experience of their lives. One of the main reasons this component comes first is the failure of sexual education as well as some of the constraints that come from home.

This statement is consistent with a study by (Robinson et al., 2017) as well as a report from the Ministry of Social and Family Development (MSF) (The Streets Times Singapore, 2017) showing that children are at greater risk of being sexually abused by someone they know in neighbourhoods or family members compared to strangers. Parents need to be equipped with knowledge of how to recognize early warning signs that can indicate child sexual abuse. They also need to know what drives individuals to commit child sexual abuse and how these individuals make friends and manipulate children to gain their trust. This item is, therefore, of the first importance in the opinion of experts. The second most important item is the interaction of outsiders - the relationship between caregivers, neighbours, and peers, which is the second socialization relationship in the child's life. According to Ishak (2006), safety refers to protecting individuals from staying safe, from protecting their lives, and from protecting them. Child sexual safety is related to the responsibility to value one's own body, to interact with both genders (understanding of gender and gender), the ability to express love in a proper way (family relationships), avoiding exploitation in friendship ( peers), recognize values, be responsible for their own behavior, communicate effectively, have a strong curiosity about issues related to sex, have communication skills and seek to limit sexuality, choose the right personality and act on values. 
While the third item is emotional and social health management activities, children need to be aware of their own emotional health in dealing with problems that may occur to them. Some of the types of emotions in a human relationship include joy, sadness, fear, anger, confusion, shame, and suspicion. The social interaction in this item will also reveal the types of social interaction, such as verbal, non-verbal, and assertive communication (Manaf, 2016). The variety of these types of interactions is important for children to learn in order to convey the information to those involved in the child's life. Physical \& reproductive health activities ranked fourth in expert opinion. Although this item has been created in the early childhood education curriculum in Malaysia (Curriculum Development Division, 2017; Curriculum Development Division, 2018) it remains an important factor for increasing children's understanding of basic sexuality education. The last item in the not-so-important position in children's sexuality education is safety activity. The goals of physical development and health care (Curriculum Development Division, 2017; Curriculum Development Division, 2018) has been emphasizing the importance of preschool children in protecting themselves and understanding the importance of maintaining their own safety. Education on personal safety not only involves the safety of the fall, the safety of the road, the safety of the use of sharp goods, or the safety of the fire, but it also includes the protection of the security against sexual abuse. Everything learned even in the concept of child safety is still called education because education plays a major role in teaching healthy sexual behavior among preschool children (Mobredi et al., 2018). Therefore, Self-Defense Training should be established in the education of preschool children to achieve the goals set out in the early childhood education curriculum in Malaysia (Curriculum Development Division, 2017; Curriculum Development Division, 2018).

\section{Conclusion}

Teachers and parents play a very important role in providing quality sexual health education to children. Self-defense training has been a transformative factor in education, especially sexuality health education for preschool children. The strong combination of these five components will respond to the Ministry of Education's call to produce globally competitive students through six key areas of leadership, thinking skills, bilingual skills, ethics and spirituality, national identity, and knowledge (Plan Education 2013-2025). Therefore, the existence of the main components of Martial Arts training is expected to give a new dimension to preschool education, especially in the field of sexual health education.

\section{References}

Abd Manaf A. R., \& Mokhtar, N. (2016). Isu-isu sokongan sosial dalam kalangan kanak-kanak mangsa penderaan seksual di institusi pemeliharaan dan perlindungan. Journal of Techno Social, 8(2).

Adler, M., \& Ziglio, E. (1996). Gazing into Oracle: Delphi method and its Application to Social Policy and Public Health. Jessica Kingsley Publisher.

Ahmad, Z. (2017). Pembangunan modul pedagogi kelas berbalik berasaskan pembelajaran reflektif untuk politeknik premier (Doctoral dissertation, Universiti Malaya).

Ahmad, Z., Muhidin, M., Wasli, P., Salihin, M., Fauzi, H. M., Ridhuan, M., Jamil, M., \& Siraj, S. 
(2014). Fuzzy Delphi Analysis for Future Environmental Education Using Interactive Animation. Nd International Seminar Teaching Excellence and Innovation, 2014(February).

Allotey, P. A., Diniz, S., DeJong, J., Delvaux, T., Gruskin, S., \& Fonn, S. (2011). Sexual and reproductive health and rights in public health education. Reproductive Health Matters. https://doi.org/10.1016/S0968-8080(11)38577-1

Asra, Ridhuan, M. J., Lim, T. A., Saedah, S., \& Aisyah, S. H. (2014). Implementation Model of Mlearning Based Discovery Learning. International Conference on Global Trends in Academic Research., 2009, 366-382.

Bugdadi, A., Sawaya, R., Olwi, D., Al-Zhrani, G., Azarnoush, H., Sabbagh, A. J., Alsideiri, G., Bajunaid, K., Alotaibi, F. E., Winkler-Schwartz, A., \& Del Maestro, R. (2018). Automaticity of Force Application During Simulated Brain Tumor Resection: Testing the Fitts and Posner Model. Journal of Surgical Education. https://doi.org/10.1016/j.jsurg.2017.06.018

Creswell, J. W., \& Creswell, D. J. (2017). Research Design: Qualitative, Quantitative, and Mixed Methods Approaches (2nd Edition). Organizational Research Methods (Vol. 6, Issue 3). http://www.amazon.com/Research-Design-Qualitative-QuantitativeApproaches/dp/0761924426

Curriclum Development Division. (2017). National Preschool Standard-Based Curriculum. Ministry of Education.

Dalley, D. (2012). The Circles of Sexuality. Minnesota Department of Health. http://www.health.state.mn.us/topics/sexualhealth/circlesofsexuality.pdf

Gansen, H. M. (2017). Reproducing (and Disrupting) Heteronormativity: Gendered Sexual Socialization in Preschool Classrooms. Sociology of Education, 90(3), 255-272. https://doi.org/10.1177/0038040717720981

Gowen, L. K., \& Winges-Yanez, N. (2014). Lesbian, Gay, Bisexual, Transgender, Queer, and Questioning Youths' perspectives of inclusive school-based sexuality education. Journal of Sex Research. https://doi.org/10.1080/00224499.2013.806648

Jones, H., \& Twiss, B. L. (1978). Forecasting Technology for Planning Decisions. Mac Millan.

Ishak, Z. (2006). Panduan kesihatan dan keselamatan kanak-kanak. Utusan Publications.

Kaufmann, A., \& Madan, M. G. (1988). Fuzzy mathematical models in engineering and management science. Amsterdam ; New York : North-Holland ; New York, N.Y., U.S.A. : Sole distributors for the U.S.A. and Canada, Elsevier Science Pub. Co.

Karimuddin, M., Ali, S. R., \& @ Adenan, A. S. (2017). Tahap Kesediaan Pengajaran Pendidikan Seksualiti Guru Pelatih Pendidikan Awal Kanak-Kanak Institut Pendidikan Guru Kampus Ipoh. Jurnal Penyelidikan Dedikasi, 12, 128-139.

Zadeh, L. A. (1965). Fuzzy sets. Information and Control., 8, 338-353.

Mobredi, K., Hasanpoor-Azghady, S. B., Azin, S. A., Haghani, H., \& Farahani, L. A. (2018). Effect of the sexual education program on the knowledge and attitude of preschoolers' mothers. Journal of Clinical and Diagnostic Research.

https://doi.org/10.7860/JCDR/2018/32702.11616

ONLINE Berita Harian. (2019). Kesedaran terhadap jenayah pedofilia semakin meningkat. https://www.bharian.com.my/berita/kes/2019/12/639068/kesedaran-terhadap-jenayahpedofilia-semakin-meningkat

Ozguner, Z., \& Ozguner, M. (2014). A Managerial Point of View on the relationship between of 
Maslow' s Hierarchy of Needs and Herzberg's Dual Factor Theory. International Journal of Business and Social Science, 5(7), 207-216.

Ragin. (2007). Qualitative Comparative analysis using Fuzzy Sets (fsQCA). In Configurational Comparative Analysis. London: Sage Publication.

Reynolds, J., Achilles, S., \& Achilles, C. (2014). Problem Analysis. Routledge.

Robinson, K. H., Smith, E., \& Davies, C. (2017). Responsibilities, tensions and ways forward: parents' perspectives on children's sexuality education. Sex Education, 17(3), 333-347. https://doi.org/10.1080/14681811.2017.1301904

Ryan, M. J. (2015). 'Does anybody here want to fight'...'No, not really, but if you care to take a swing at me...'the cultivation of a warrior's habitus in a Venezuelan combative art. Ido Movement for Culture. Journal of Martial Arts Anthropology, 3(15), 1-7.

Schmidt, S. C., Wandersman, A., \& Hills, K. J. (2015). Evidence-Based Sexuality Education Programs in Schools: Do They Align with the National Sexuality Education Standards? American Journal of Sexuality Education, 10(2), 177-195. https://doi.org/10.1080/15546128.2015.1025937

Yusop, Y. M. (2013). The Needs Analysis in Self-Concept Module Development. The Malaysian Online Journal of Educational Science, 3(1), 44-55. www.moj-es.net 